\title{
Cystatin C -a Promising Marker of Glomerular Filtration Rate
}

\author{
Nowrase Jahan ${ }^{1}$, Sohani Ferdousi ${ }^{1}$ \\ ${ }^{1}$ Dept of Biochemistry, National Institute of Kidney Diseases and Urology
}

\begin{abstract}
Glomerular filtration rate (GFR) is the best single measure of overall function of kidney. GFR is routinely assessed by measuring the concentration of endogenous serum markers such as blood urea nitrogen and serum creatinine ( $\mathrm{SCr}$ ). Although widely used these endogenous marker are not ideal and do not perform optimally in certain clinical settings. The purpose of this review is to critically review the potential utility of Cys $\mathrm{C}$ as a new promosing markers of GFR and to review whether Cys $\mathrm{C}$ had any advantage over routinely used endogenous marker in different population group.

Key Words: Glomerular Filtration Rate (GFR), Serum Creatinine (Scr), Blood Urea, cystatin C (Cys C)
\end{abstract}

\section{Introduction}

Glomerular filtration rate is defined as the volume of plasma that can be completely cleared of a particular substance by the kidneys in a unit of time ${ }^{1}$. GFR is the sum of filtration rate of all functioning nephrons. GFR can be measured only indirectly ${ }^{2}$. The gold standard for determining GFR is to measure the clearance of exogenous substance such as inulin, iohexol, ${ }^{51} \mathrm{Cr}$ - EDTA, ${ }^{99} \mathrm{Tc}-$ labeled diehylenetriamine penta acetic acid (DTPA), or 25I labeled iothalamate. These techniques, however, are time-consuming, labour- intensive, expensive, and require administration of substances that make them incompatible with routine monitoring. Thus the measurement of endogenous substance is a common practice. Properties of ideal endogenous blood substance to estimate GFR should include, release into the blood stream at a constant rate, free filtration by the glomerulus, no reabsorbtion or secretion by renal tubules, and exclusively eliminated by the kidneys ${ }^{3}$.

Blood urea was the first endogenous marker to assess renal function1. Urea is freely filtered by the glomerulous and not secreted by the tubues. Limitation of urea as a GFR marker is its passive reabsorb and its return to blood stream. Thus serum urea concentration will under estimate GFR. Furthermore, its concentration in blood can vary with diet, hepatic function, and numerous diseases states ${ }^{4}$.

Serum creatinine is widely used as an indirect marker to assess GFR 5. But serum creatinine concentration is affected by factors that are independent of GFR, such as age, race, muscle mass, gender, medication use, and catabolic state $^{6}$. Moreover, serum creatinine concentrations are insensitive to mild to moderate reductions of $\mathrm{GFR}^{7}$. In addition measurement of creatinine by the common Jaffe methods is subject to numerous analytical interferences due to presence of non-creatinine chromogen such as bilirubin, ketones, uric acid and some antibiotics ${ }^{8}$. Serum creatinine is not reabsorbed by the kidney tubules but secreted in small amount, which are subject to intra and inter individual variation. As plasma concentration increase, tubular secretion of Scr increases, leading to over estimation of $\mathrm{GFR}^{9}$. Thus serum creatinine is a crude indicator of a significantly impaired renal function $(<50 \%)$. Furthermore, more rapid change in glomeruler 
filtration are not detected by $\mathrm{SCr}^{10}$. The measurement of urinary creatinine clearance overcomes some of limitations of serum creatinine but remains inaccurate because of collection errors and changes in creatinine excretion ${ }^{11}$. Several prediction equation to estimate GFR from serum creatinine and other variables (age, sex, race, body weight, albumin) is therefore recommended by kidney foundation. Mostly used equations are Cockcroft-Gault ${ }^{12}$ and modification of diet in renal diseases (MDRD) equations in case of adult ${ }^{13}$. The commonly used equation for children are Schwarth and Counahan14. However, this prediction equation has not validated in subject with normal and supernormal GFR ${ }^{15}$.

Thus, despite of their common use, blood urea and serum creatinine have limitations as renal markers, and search for an ideal endogenous marker continues ${ }^{16}$. Here, we reviewed recent studies of another endogenous substance, cystatin $\mathrm{C}$ (Cys C) as a marker of GFR estimation.

\section{Cystatin C as GFR marker}

Cys $\mathrm{C}$ is a protein having $\mathrm{MW}$ of $13 \mathrm{KDa}$ containing 122 amino acids that belongs to a family of cysteine proteinase inhibitors. It is a product of a housekeeping gene expressed in all nucleated cells and is produced at a constant rate $^{17}$. Because of its smaller size and cationic nature, it is freely filtered by the glomerulus. It is not secreted, but is reabsorbed by tubular cells and subsequently catabolized so that it does not return to the blood ${ }^{18}$. Again, Cys $\mathrm{C}$ is not affected by age, inflammatory processes, change of body mass, nutrition, fever or gender. Thus, due to stable synthesis, lack of degradation and tubular secretion, Cys $\mathrm{C}$ is only influnced by renal GFR, making it an ideal endogenous marker of GFR ${ }^{19}$.

Multiple studies have validated the use of Cys C as a renal marker in adult patients ${ }^{20-24}$. In addition, two studies suggested that, Cys $\mathrm{C}$ was more sensitive marker than Scr for small changes in $\mathrm{GFR}^{20,24}$. Recent studies further suggest that Cys $\mathrm{C}$ is an earlier indicator of mild renal failure $25-26$.

\section{Methods for measurement of Cys C}

Cys $\mathrm{C}$ can be messured by immunoassay. Recently automated immunoassays utilizing latex or polystyrene particles coated with CysC coated antibodies were developed. There are two different version of latex immunoassay for Cys C- one based on turbimetry- particle enhanced turbimetric immunoassay (PETIA)27,28,29 and another based on nephelometry- particle enhanced nephelomertic immunoassay (PENIA) $)^{30,31}$.

\section{Cys $\mathrm{C}$ in pediatric population}

Cys $\mathrm{C}$ has been postulated to have an advantage over Scr in pediatric population because of low muscle mass in children, which lead to very low Scr values. Therefore, it may be difficult to detect accurately, small changes in GFR with Scr in children $<4$ years of age in whom normal Scr values are only $0.2-0.4 \mathrm{mg} / \mathrm{L}$. On the other hand, plasma concentration of Cys $\mathrm{C}$ appears to be rather constant in children $>1$ year of age and similar to that of adults ${ }^{32-35}$. These studies also showed that immediately after birth, Cys C values were approximately twice that of older children and adults but that they reaches a mean value of $0.95 \mathrm{mg} / \mathrm{L}$ by 1 to 2 months of age. Studies suggested that blood Cys $\mathrm{C}$ level was higher in premature infant ${ }^{36-38}$. Cys $\mathrm{C}$ does not cross placental barrier, so serum Cys $\mathrm{C}$ level in new born is not influenced by maternal serum Cys C leve 36 .

\section{Cys $\mathrm{C}$ in diabetic patients}

Cys $\mathrm{C}$ has reported to be a reliable marker of GFR in patients with mild to moderate impairment of kidney functions in both type 1 and type 2 diabetic patients39. Cys $\mathrm{C}$ is a better indicator than creatinine in diabetic patients and showed good correlation with changes in GFR over two years, making it a useful measure for follow up of patients with diabetes40. Even Cys $\mathrm{C}$ can detect renal involvement earlier than microalbuminuria in type 1 diabetes ${ }^{41}$. 
Cystatin C -a Promising Marker of Glomerular Filtration Rate $\mathrm{Cys} \mathrm{C}$ in renal transplantation

Serum Cys C determination is used for rapid and accurate assessment of renal function in patients with renal transplant. Acute rejection or infections, both are common problems in patients with renal transplants. Cys $\mathrm{C}$ continues to provide a precise assessment of GFR while creatinine would vary dramatically. Thus Cys $\mathrm{C}$ allows early recognition and accurate dosing of different immunosuppressive drugs ${ }^{42}$.

\section{Cys $\mathrm{C}$ in acute kidney injury (AKI)}

Cys $\mathrm{C}$ has been reported to increase about one to two days earlier than serum creatinine does in patients developing $\mathrm{AKI}^{43}$.

\section{Other population groups}

GFR declines with age and Cys $\mathrm{C}$ reflects true kidney function better in older peoples as it is not influenced by muscle mass.

Patients with advanced cirrhosis who have an abnormal GFR can present with normal Scr values because of their decreased muscle mass and abnormal excretion of creatinine ${ }^{44,45}$. But Cys $\mathrm{C}$ may be a better marker in cirrhotic patients ${ }^{46}$.

In obstretrics, pre-eclamptic patients with altered kidney functions are more likely to be detected by $\mathrm{Cys} C$ than serum creatinine estimation ${ }^{47}$.

On conditions ccurate estimation of GFR is essential for diagnosis, staging and management of chronic kidney diseases. Cys C is clearly an attractive endogenous marker to assess renal function. The advantage of Cys $\mathrm{C}$ as an earlier marker of mild damage as reported in most studies is due to several unique properties of Cys C compared with creatinine. The most of these are, its constant production, it is independent of muscle mass, age or sex and lack of its renal secretion or reabsorption back into the blood stream. Cys $\mathrm{C}$ is also more sensitive marker than serum creatinine in case of children and also older groups. Cys $\mathrm{C}$ is superior to creatinine in estimating GFR in other patients groups such as kidney transplant, diabetic patients and cirrhotic patients with CKD etc. So, this review suggests that Cys $\mathrm{C}$ can detect GFR more accurately than serum cratinine can.

\section{References}

1. Smith HW. The kidney: structure and function in health disease. Oxford University Press New York. 1951: 63-66.

2. National kidney Foundation. K/DOQI clinical practice guidelines for chronic kidney disease: evaluation. Classification and stratification. Am J kidney Dis 2002; 39 (suppl 1): s1-S246.

3. Laterza OF, Price CP, Scott MG. Cystatis C : As improved estimator of glomerular filtration rate? Clin Chem 2002; 48: 699-707.

4. Newman DJ, Price CP. Renal function and nitrogen metabolites. Burtis CA Ashwood ER eds Teitz textbook of clinical chemistry. WB Saunders Philadejphia. 1999: 1204 - 1270

5. Rigalleau V, lasseur C, Perlemoine C, Barthe N, Raffatin C, Liu C, Chauveau P, Bailet-Blanco L, Beauvieux MC, Combe C, Gin H. Eatimation of glomerular filtration rate in diabetic subjects. Diabetic care. 2005; 28: 838-843.

6. White C,Akbari A, Hossain N, Dinh L, Filler G, Lapage N, Knoll GA. Estimation of glomerular filtration rate in kidney tranasplantation: A comparison between serum creatinine and cyctatin $\mathrm{C}$ based methods. J Am Soc nephrol. 2005; 16: 3736-3770.

7. Schwartz GJ, Haycock GB, Edelmann CM, Spitzer A. A simple estimate of glomerular filtration rate in children derived from body length and plasma creatinine. Pediatrics 1976; 58: 259-263.

8. Perrone RD, Madias NE, Levey AS. Serum creatinine as an index of renal function: new insights into old concepts. Clin Chem. 1992; 38: 1933-1953.

9. Levey AS, Berg RL, Gassman JJ, Hall PM, Walker WG. Creatinine filtration, secretionand excretion during progressive renal disease. Kidney Int. 1989; 36 (Suppl 27): S73-S80.

10. Perrone RD, Madias NE, Levey AS. Serum creatinine as an index of renal function: new insights into old concepts. Clin Chem 1992; 38: 1933-1953.

11. Coresh J, AstorBC, Mcquillan G, Kusek J, Greene T, Van lante F, Levey AS. Calibration and random variation of the serum creatinine assay as critical elements of using equations to estimate glomerular filtration rate. Am J Kidney Dis.2002; 39: 920-929. 
12. Cockcroft DW and Gault HM, Prediction of creatinine clearance from serum serum creatinine. Nephron 1976; 16: 31-41.

13. Levey AS, Corash J, Balk E, Kausz AT, Levin A, Steffes MW, Hogg RJ, Perrone RD, Lau J, Eknoyan G. National Kidney foundation practice guidelines for chronic kidney disease: evaluation, classification and stratification. Ann Intern Med 2003; 139: 137-147.

14. European best practice guidelines for haemodialysis (PART 1). Measurement of renal function. Nephrol Dial transplant 2002; 17: 7-9.

15 Vervoot G, Willems HL, Wetzels JFM. Assessment of glomerular filtration rate in healthy subjects and normoalbuminuric diabetic patients: validity of a new (MDRD) prediction equation. Nephrol Dial Tranplant. 2002; 17: 1909-1913.

16. Swan SK. The search continues- an ideal marker for GFR. Clin Chem. !997; 43: 913-914.

17. Abrahamson M, Olafsson I, Palsodottir A, Ulvsback M, lundwall A, Jensson A, Srtucture and expression of human cystatin C gene. Biochem J 1990; 268: 287-294.

18. Grubb A. Diagnostic value of analysis of cystatin C and protein $\mathrm{HC}$ in biological fluids. Clin Chem. 1992; 38: S20-S27.

19. Shemesh O, Golbetz H, Kriss JP, Myers BD. Limitation of creatinine as a filtration marker in glomerulopathic patients. Kidney Int 1985; 28: 830-838.

20. Newman DJ, Thakkar H, Edwards RG, Wilkie M, White T, Grubb A, Serum cystatin C measured by automated immunoassay: a more sensitive marker of changes of GFR than serum creatinine. Kidney Int. 1995; 47; 312-318.

21. Kyhse J, Schmidt C, Nordin G. Anderson B, Nilsson-Ehle P, Lindstrom V, Serum cystatin C, determind by a rapid, automated particle enhanced turbimetric method, is a better marker than serum creatinine for glomerular filtration rate. Clin Chem. 1994; 40: 1921-1926.

22. Grubb A, Simonsen O, Truedsson L, Thysell $\mathrm{H}$. Serum concentration of cystatin C, factor D and B 2 microglobulin as a measure of glomerular filtration rate. Acta Med Scand 1985: 218: 499-503.

23. Randers E, Kristenson JH, Erlandsen EJ, Danielson $\mathrm{H}$. Serum cystatin $\mathrm{C}$ as a marker of renal function. Scand J Clin Lab Invest 1898; 58: 585-592.
24.Newman Dj, Thakkar H, Edwards RG, Wilkie M, White T, Grubb AO, Serum cystatin C: a replacement for creatinine as a biochemical marker for GFR. Kidney Int 1994;46: S20-S21.

25. Filser D and Ritz E. Serum cystatin C concentration as a marker of renal dysfunction in elderly. Am $\mathrm{J}$ Kidney Dis 2001;37: 79-83.

26. Randers E, Erlandsen EJ, Pederson OL, Halsing C, Danielsen $\mathrm{H}$. Serum cystatin $\mathrm{C}$ as an endogenous parameter of the renal function in patients with normal or moderately impaired kidney function. Clin Nephrol 2000; 54:203 209.

27. Norlund L, Fex G, Lanke J, VonSchenck H,Nilsson JE, Leksell H, Reference intervals for glomrular filtration rate and cell-proliferation marker: serum cystatin C and serum B 2-microglobulin/cystatin C ratio. Scand J Clin Lab Invest.1997;57:463-470.

28. Erlandsen EJ, Randers E, Kristensen JH. intervals for serum cystatin $\mathrm{C}$ and serum creatinine in adults. Clin Chem Lab Med 1998; 36:393-397.

29. Norlund L, Grubb A, Fex G, Leksell H, Nilsson JE, Schenck $\mathrm{H}$. The increase in plasma homocysteine concentrations with age is party due to the deterioration of renal function as determined by plasma cystatin C. Clin Chem Lab Med 1998; 36: 175-178.

30. Finney H, Newman DJ, Gruber W, Merle P, Price CP. Initial evaluation of cystatin $\mathrm{C}$ measurement by particle enhanced immunonephelometry on the Behring nephelometer ystems (BNA, BN2). Clin Chem 1997;43: 1016-1022.

31. Mussap M, Ruzzante N, Varagnolo M, Plebani M. Quantititive automated particle enhanced immunonephelometric assay for the routine measurement of human cystatin C. Clin Chem1998;36: 859-865.

32. Randers E, Krue S, Erlandsen EJ, Danielson H, Hansen LG. Reference interval for cystatin $\mathrm{C}$ in children.Clin Chem. 1999; 45: 1856-1858.

33. Filler G, Witt I, Priem F, Ehrich JHH, Jung K. Are cystatin $C$ and B 2 microglobulin better marker than serum creatinine for prediction of a glomerular filtration rate in pediatric subjects?. Clin Chem 1997; 43: 1077-1078.

34. Bokenkamp A, Domanetzki M, Zinck R, Schumann G, Byrd D, Brodehi J. Cystatin C- a new marker of glomerular filtration rate in children independent of age and height. Pediatrics 1998; 101: 875-881. 
35. Helin I, Axenram M, Grubb A. Serum cystatin C as a determinant of glomerular filtration rate in children. Clin Chem 1998;49: 221-225.

36. Harmonien A, Ylinen E, Ala-Houhala M, Janas M, Kaila M, Kouri T. Reference interval for cystatin C in pre and full-term infant and children. Pediatr Nephrol 2000; 15: 105-108.

37. Finney H, Newman DJ, Thakkar H, Fell JME, Price $\mathrm{CP}$. Reference ranges for plasma cystatin $\mathrm{C}$ and creatinine measurements in premature infants, neonates, and older children. Arch Dis Child 2000; 82: 71-75.

38. Montini G, Amici, Zacchello G. Plasma cystatin values and inulin clearance in premature neonates. Pediatr Neplrol 2000, 16: 463-464.

39. Willems D, Walf F, Mekhall F, Gillet C. Cystatin $\mathrm{C}$ for early detection of renal impairment in diabetes, Clin Biochem 2009; 42: 108-110.

40. Hok F, Kemprman FA, Krediet RT. A comparison between cystatin $\mathrm{C}$, plasma creatinine and the Cockroft and Gault formula for estimation of glomerular filtration rate. Nephrol Dial Transplant 2003; 18: 2024-2031.

41. Rosolowsky ET, Nlewczas MA, Rcoclello LH. Between hyper filtration and impairment: demystifying early renal functional changes in diabetic nepropathy. Diabetes Res Clin Pract 2008;82: S46 -S53
42. Risch L,Blumberg A, Huber A. Rapid and accurate assessment of glomerular filtration rate in patients with renal transplants using serum cystatin C. Nephrol Dial transplant 1999; 14 : 1991-1996.

43. Herget-Rosenthal S, Marggrat G, Husing J, Early detection of acute renal faiure by serum cystatin $\mathrm{C}$. Kidney Intl 2004; 67: 2089-2100.

44. Caregaro L, Menon F, Angei P, Amodio P, Merkel C, Bortoluzzi A, Limitation of serum creatinine level and creatinine clearance as filtration marker in cirrhosis. Arch Intern Med 1994; 154: 201-205.

45. Takabatake $\mathrm{T}$, Ohta $\mathrm{H}$, Ishida $\mathrm{Y}$, Hara $\mathrm{H}$, Ushiogi Y, Hattori N. Low serum creatinine levels in severe hepatic disease. Arch Intern Med 1988; 148: 13131315.

46. O'Rlordan SE, Webb MC, Stowe HJ, Simpson DE, Kandarpa M, Coakley AJ, Cystatin C improves the detection of mild renal dysfunction in older patients. Ann Clin Biochem. 2003; 40:648-655.

47. Stevens H, Wide- Swensson D, Grubb A. Serum cystatin $\mathrm{C}$ is a better marker for preeclamsia than serum creatinine or urate. Scand J Clin Lab Invest. 2001; 61: 575-580. 